\title{
RECENT FINANCIAL LEGISLATION IN NEW JERSEY ${ }^{1}$
}

\author{
BY RALPH E. GEORGE \\ Whitman College
}

$\mathrm{I}^{\mathrm{N}}$ $\mathrm{N}$ the last two years, the legislature of New Jersey has passed a series of laws regulating the management of municipal finances which make possible a marked advance in the financial administration of the cities of that state. This legislation was initiated and supported by the commission for the survey of municipal financing, appointed by the speaker of the house of assembly. Perhaps the commission is more commonly known as the Pierson commission, in honor of its energetic chairman, the Hon. Arthur N. Pierson. Under his leadership, the 1916 legislature passed a law regulating the management of debts; while the 1917 legislature added to this several statutes regulating floating debt, the payment of permanent debt, the form and procedure of budget legislation, and also established the state department of municipal accounts.

This legislation falls roughly into four parts: That concerned with the management of city debt, that establishing a budget system; that determining the procedure for the attainment of uniform accounts and reports, and provision for the enforcement of the other regulations imposed. Under these heads the laws passed by the 1916 and 1917 legislature will be briefly described.

\section{MUNICIPAL INDEBTEDNESS}

Legislation with regard to municipal indebtedness is of interest in all states at the present time, since there is probably no branch of municipal finance so mishandled. New Jersey cities have erred in common with other cities. As a result of its investigations, the commission in 1916 made the following report:

The survey has revealed that many of the municipalities and counties have not been meeting the cost of the conduct of their affairs out of the revenues applicable to current year. There have been employed a multitude of schemes and expedients to conceal such unbusinesslike practices, too numerous and too complicated to recite in this report. This has brought to many communities floating debts which have been periodically funded into long term bonds, and the process repeated in some instances by refunding floating debt bonds. It is evident that these practices have been employed for the most part to avoid an increase in tax rate. Such a policy is too dangerous to be further sanctioned by the statutes.

1 This summary of the recent New Jersey legislation is based upon Laws of New Jersey, 1916, 1917, particularly chapter 252 of the Laws of 1916, and chapters 110, 192, $155,212,154$, and 155 of the Laws of 1917 . Additional information of interest is contained in the reports of the commission for the survey of municipal financing for 1916 and 1917. 
Your commission earnestly contends that all expenditures for the maintenance, upkeep and repair of all departments of municipal activities: should be met by current revenues. This is the pay as you go policy.

The floating indebtedness now present in any municipality, which is not supported by corresponding live and dependable assets, should be immediately refunded, that this overshadowing burden may not complicate nor hinder the proper financing of future municipal needs.

The adoption of a more businesslike system is now required by the legislation of 1916 which limits the term of bonds to the life of the improvement, prohibits refunding of bonds, specifies the purposes for which the debt may be incurred, requires the use of installment bonds, sets a limit beyond which debts may not go, governs the method of selling bonds, and prescribes the method of raising money in anticipation of tax revenues and in cases of emergency.

In the first place, bonds can not be issued for a period longer than the life of the improvement and this requirement is made specific by the insertion in the law of limits beyond which bonds issued for different. purposes may not run, as follows:

Acquisition, construction, and reconstruction of sewer systems . . . . . . 40 years

"

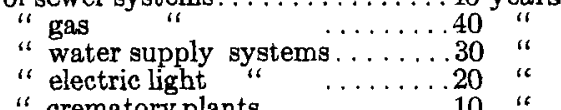

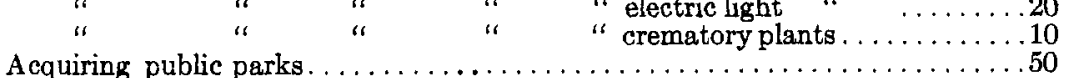

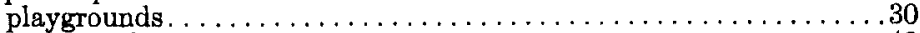

other lands. . . . . . . . . . . . .

buildings

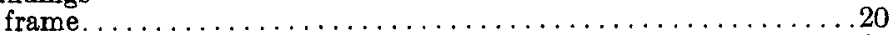

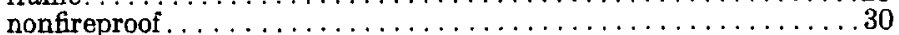

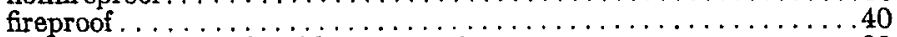

Construction or reconstruction of bridges, stone, iron or cement . . . . . . . . 30 streets

Land and gravel . . . .

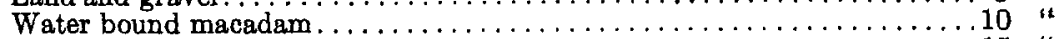

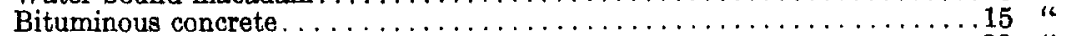

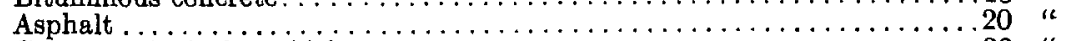

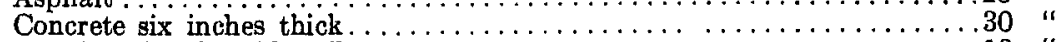

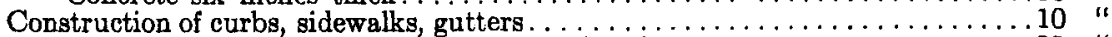

Installation municipal telephones, police and fire alarms, etc. . . . .

Purchase of vehicles. . . . . .

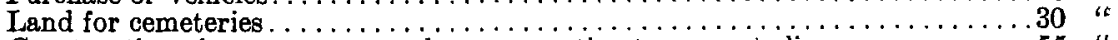

Construction of sewer, water, and gas connection to property line ........55 "i

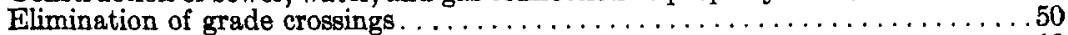

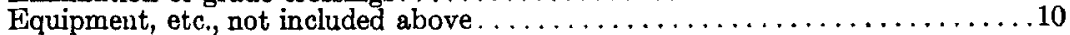

That the debts incurred for the above purpose may not overrun the allotted time, is secured by the provisions that such bonds can not be refunded and that all these bonds must be in serial form. The serial form of a bond is required by the following provision:

All bonds hereafter issued by any such municipality shall mature in annual installments commencing not more than two years from their date, and no installment shall be more than fifty per centum in excess of the amount of the smallest prior installment. 
Yet another limitation imposed upon municipal debts is the provision that the net debts may not exceed seven per cent of the assessed valueaverage for the three preceding years with certain special exceptions which might raise the limit to nine per cent. The net debt is defined in the law in detailed form, but roughly the method for computing the legally permissible debt is as follows: In the first place the gross debt is secured by adding the bonded debt, special assessment issues, utility, schools, parks, ${ }^{2}$ and the other obligations; from the sum of these classes of debt to find the net debt the following are dedicated: special assessments levied and uncollected, special assessments to be collected and applied to present debt, debt not over three per cent of the assessed valuation where this debt has been incurred for utilities which are paying the interest and redeeming the principal from current revenues, debts incurred for water supply systems, funds and sinking funds, taxes levied for the retirement of the debt, unpaid taxes for the last three years, debts incurred for protection from the seas, and amounts otherwise due the city. This definition would seem to be more elastic and at the same time more easily understood and applied than the regulations now used in many states.

\section{CHANGE IN THE METHODS OF SELLING BONDS}

In the new laws an interesting change is made in the method of selling. bonds. At present most cities sell their bonds at a considerable premium. and thus often more money is received than is actually needed. This premium is generally used to pay current bills instead of being retained for the ultimate liquidation of the loan. In order to prevent the cities. from securing money in this fashion for current expenses, the New Jersey legislation provides that the municipality shall determine what money it. needs and what kinds of bonds it will issue and that it shall then call for bids, awarding the bonds to the bidder who will offer to take the least. number of bonds in return for the money advanced. In this way practically no premium exists and the city gets exactly what money it needs.

\section{SHORT TERM LOANS}

The regulations so far given apply only to long time loans, but nearly every city borrows money occasionally for short time periods only. Of this class of loans the anticipation of taxes is probably the most common example, since taxes are not usually paid until well on in the local fiscal year and since the city must raise funds at the beginning of the year to. meet the current expenses. The New Jersey statutes provide that the cities may borrow up to 95 per cent of the taxes voted in the budget. In case these taxes are not paid promptly, tax revenue notes can be issued.

${ }^{2}$ If these debts are incurred by other political bodies, such for example, as the county, they are counted only for that governmental unit, not for the city.-R. E. G. 
to the amount of delinquent taxes. But here again, provision is made that these shall not be permanent charges, for all tax revenue notes unpaid at the end of three years must be raised in the tax levy of the fourth year.

Yet another short-period debt is provided for in the case of emergency notes, which can be issued only upon vote of two-thirds of the local legislative body. Such notes, however, must be included in the next tax unJess inclusion would raise the tax rate by more than one-third of one mill, when the sum needed to retire them can be raised in annual installments of not less than one-third mill.

The provisions for future debt management thus cover two classes of debt: long time and temporary. The first class is restricted as to purpose and as to time, it must be paid in annual installments, and it must be sold in such a way that no substantial premium can be secured for current use. The tax revenue notes issued in anticipation of delinquent taxes can under no circumstances run longer than three years, while the emergency notes must be paid off at the rate of at least one-third mill tax per year. In these regulations little opportunity apparently exists for the development of large debts representing vanished values.

\section{TRANSITION FROM OLD TO NEW SYSTEM}

The provisions so far considered deal only with the future debt management of the cities and leave untouched the very difficult problem of making the transition from the old method, or lack of method, to the new system. In connection with the latter problem, some of the greatest obstacles to reform are to be found, but the New Jersey legislature has provided a fairly easy method of making the change, in the case both of the bonded debt and of the floating debt. In the first place, the present bonded debt must be retired gradually by means of the sinking fund, which must be maintained on an interest basis of three and one-half, per cent, that is, the money annually turned over to the sinking fund must be sufficient when invested at three and one-half per cent to meet the bonds in full at maturity. If, however, the sinking funds earns more in any one year than the rate of interest specified, the excess earnings may be deducted from the amount paid the sinking fund from the tax rate during the following year. Moreover, where there is at present a deficit in the sinking fund, a somewhat common condition, this shortage must be made up by a levy of at least one-fifth of a mill tax per year.

In addition to these requirements for repaying the funded debt, careful provisions have been adopted for the retirement of the floating debt. Two classes of floating debt have been considered by the legislature: obligations representing money advanced to the cities on account of delinquent taxes, and general floating debt. The cities are required to refund all delinquent taxes by means of the following classes of debt: tax revenue notes of 1916, representing that year's delinquent taxes, 
which notes must be redeemed in 1919 , tax revenue notes of 1915 , to be paid by 1918 , and tax revenue notes of 1914, to be paid in.1917. In case it is discovered by the time these notes are due that the taxes represented have been remitted or for other reasons are uncollectible, the deficiency must be paid in five equal installments from the tax levy.

So far as other floating debt is concerned bonds or notes must be issued to redeem the same, such bonds to be payable in equal annual installments, each of which can not be less than one-fifth of one mill tax, to run not longer than 20 years. In these ways, the transition from the old to the new method is rendered relatively easy both for permanent and short time debts, spread out as it is over a considerable period of time, and should not cause the cities any great hardships.

\section{THE BUDGET}

The second general feature of the municipal finances covered by this series of laws is the budget. Here the commission recommended and the legislature permitted a choice by the city between the department and the segregated budget, on the ground that the former where feasible allowed greater administrative efficiency. In the words of the commission:

The object sought in the budget law is to have the definite program of administration clearly set forth, both as to sources of revenue and purposes of expenditure, giving the taxpayers opportunity for analyzing and discussing the budget provisions prior to its adoption and operation.

To secure these ends, a uniform plan is adopted, requiring the approval of the budget by the 25th day of the fiscal year and its final adoption by the 40th day, providing for public hearings on the budget prior to its approval and adoption, prohibiting changes from this budget of more than 10 per cent on any item unless a new public hearing is first held, and specifying what shall be included in the budget proposals. With regard to the latter specifications, the budget must include statements of total anticipated revenues, of total expenditures according to purposes, compared with the same items for previous years, of the surplus in the surplus revenue account, and of the amount which must be raised by taxation. Changes in the appropriations after adoption may not vary more than 10 per cent on any item, or more than five per cent of the total appropriation, nor may the amount set aside for contingent expenses exceed three per cent of the total. These requirements are slightly modified by the permission to make transfers in the last two weeks of the year upon vote of the governing body.

An interesting part of this law is the provision of a surplus revenue account, which can be used for financing purposes, thus avoiding the periodical loans needed by so many cities before the taxes are paid. To this surplus revenue account must be carried all unexpended balances. If there develops any shortage in the municipal receipts, the city can 
borrow from this account but no appropriation can be made from it after the budget has been adopted. (It may serve as a basis for appropriations, however, prior to passage of the budget.)

\section{DEPARTMENT OF MUNICIPAL ACCOUNTS}

The third and fourth objects of this legislation, namely, the attainment of uniform municipal accounts and provision for enforcement of the acts already outlined are largely secured through the establishment of a new state administrative body, the department of municipal accounts. A commissioner of municipal accounts is to be appointed by the state treasurer, to receive a salary of $\$ 3,600$ per annum. While he is given power to require the adoption of uniform accounting and reporting and to enforce all state laws dealing with local finances his main duties are apparently concerned with the enforcement of debt legislation. $\mathrm{He}$ is given power to determine the adequacy of the municipal sinking funds and to require the levy of additional taxes to make good any deficiency in these funds. To make this power effective he must through his staff audit the accounts of the various sinking funds and he receives annual reports from cities of all debt transactions in accordance with forms he prescribes. Not only does he have control over all sinking funds, but he is charged with the supervision of the procedure for any incurrence of debt, determining whether the debts can or can not be legally incurred.

In summary, this series of laws may be said to embody many of the most successful features of sound municipal financing. For the solution of the troublesome debt problem, the legislature has practically adopted the view that the most important need is the assurance that the debts will be paid within the lifetime of the improvements to pay for which they were issued. More emphasis is placed upon repayment than upon the amount of the debt. Then, New Jersey has worked out a fairly easy method of making the change to the new system, since while the old debts must be paid off, ample time is allowed the cities to do this without. seriously disarranging their financial plans.

The budget legislation is fortunate in that it insures the fundamental essentials of a definite yearly program, of ample publicity and of fairly good means for insuring that the plan will be carried out in practice, at the same time that it leaves the cities free to adopt the type of budget best suited to their various conditions and management. By this series. of laws, furthermore, New Jersey has joined the group of states which believe in uniform accounting, at least uniform reporting, methods and has organized a state department to assure the success of this feature of the legislation. The power of the commissioner of municipal accounts, while adequate, so far as the law is concerned, can not prove very offensive to city officials since the latter are not limited greatly in the determination of policy so long as the sound financial methods prescribed are followed. 
Finally, the provisions that bonds shall be sold on what is practically an interest basis and the establishment of surplus revenue account for financing purposes are distinct advances. The execution of these laws deserves the closest attention by students of municipal finance and by city officials throughout the country. Not so rigid and far-reaching as some state legislation, the New Jersey laws are designed to attain the end of good municipal financing without impairing the essential powers of the cities.

\title{
EFFICIENCY IN STATE SCHOOL SYSTEMS
}

\author{
BY WILFORD E. TALBERT ${ }^{1}$
}

San Francisco

$\mathrm{T}$

HE world war, the high cost of living, the general improvements in methods of conducting private business-these and many other factors have led to a recent widespread interest in the matter of efficiency and economy in the administration of public affairs, and particularly in the management of the public schools which are responsible for approximately one-third of all governmental costs.

\section{THE MEANING OF EFFICIENCY AND ECONOMY}

In the sense in which we shall use it in this article, efficiency simply means "the one best way of doing things." It implies the application of scientific methods to the solution of administrative problems, the substitution of facts for mere popular opinions or prevailing traditions, the discarding of "main strength and awkwardness" for intelligent and well-directed activity, and the elimination of whatever of time, or effort, or expense, or misery may be found to be unnecessary.

Economy, too, is subject to so many different interpretations that it may be well to state our own definition at the outset. By economy we do not mean subtraction, but we do mean the elimination of unnecessary waste. True economy makes for efficiency; false or "poor" economy does not. Efficiency always promotes true economy.

THE SCHOOL PROBLEM STATED

The public schools now call for approximately one-third of all governmental revenues, and statistics show that, despite the enlargement of other governmental functions, the cost of education still continues to advance more rapidly than that of other departments. In California, the cost of the lower schools has doubled every seven years since 1900 . This means that by 1931 the schools will cost four times what they do now!

1 Assistant in charge, bureau of educational inyestigation, taxpayers' association of California; consulting director of the department of reference and research in the Oakland schools for three years in active charge. 